\title{
ECOLOGY OF THE COLD-ADAPTED SPECIES NEBRIA GERMARI (COLEOPTERA: CARABIDAE): THE ROLE OF SUPRAGLACIAL STONY DEBRIS AS REFUGIUM DURING THE CURRENT INTERGLACIAL PERIOD
}

\author{
Barbara Valle ${ }^{1}$, Roberto Ambrosini ${ }^{2}$, Marco Caccianiga ${ }^{3}$ and Mauro Gobbi ${ }^{4}$ \\ ${ }^{1}$ Department of Biosciences, Università degli Studi di Milano, Via Celoria 26 - 20133 Milano Italy \\ E-mail: barbara.valle@unimi.it; https://orcid.org/0000-0003-4829-4776 \\ ${ }^{2}$ Department of Environmental Science and Policy, Università degli Studi di Milano, Via Celoria 26 - \\ 20133 Milano, Italy; E-mail: roberto.ambrosini@unimi.it; https://orcid.org/0000-0002-7148-1468 \\ ${ }^{3}$ Department of Biosciences, Università degli Studi di Milano, Via Celoria 26 - 20133 Milano, Italy \\ E-mail: marco.caccianiga@unimi.it; https://orcid.org/0000-0001-9715-1830 \\ ${ }^{4}$ MUSE-Science Museum of Trento, Corso del Lavoro e della Scienza 3, 38122 Trento, Italy \\ E-mail: Mauro.Gobbi@muse.it,https://orcid.org/0000-0002-1704-4857
}

In the current scenario of climate change, cold-adapted insects are among the most threatened organisms in high-altitude habitats of the Alps. Upslope shifts and changes in phenology are two of the most investigated responses to climate change, but there is an increasing interest in evaluating the presence of high-altitude landforms acting as refugia.

Nebria germari Heer, 1837 (Coleoptera: Carabidae) is a hygrophilic and cold-adapted species that still exhibits large populations on supraglacial debris of the Eastern Alps.

This work aims at describing the ecology and phenology of the populations living on supraglacial debris. To this end, we analysed the populations from three Dolomitic glaciers whose surfaces are partially covered by stony debris.

We found that supraglacial debris is characterised by more stable colder and wetter conditions than the surrounding debris slopes and by a shorter snow-free period. The populations found on supraglacial debris were spring breeders, differently from those documented in the 1980s on Dolomitic high alpine grasslands, which were reported as autumn breeders. Currently, Nebria germari seems, therefore, to find a suitable habitat on supraglacial debris, where micrometeorological conditions are appropriate for its life-cycle and competition and predation are reduced.

Keywords: Coleoptera, Carabidae, climate change, cold-adapted species, warm-stage refugia, glacier retreat.

\section{INTRODUCTION}

In the current scenario of global warming, high altitude habitats are among the most threatened (Cauvy-Fraunié \& Dangles 2019, Fattorini et al. 2020). Some of the most visible effects of climate change are the reduction in glaciers mass and surface and the increase of debris cover on their surface, because of the reduction of the pressure of the ice volume on the glacier headwalls and the amplification of frost and heat weathering that increases erosion. This phenomenon is transforming many Alpine glaciers into 
debris-covered glaciers (Citterio et al. 2007, Paul et al. 2007, KraAijenbrink et al. 2017, Tielidze et al. 2020). The debris cover has a strong impact on the dynamic of glaciers: when the debris is thicker than $3-5 \mathrm{~cm}$, it reduces the rate of ice ablation, with critical thickness depending on the lithological nature of the debris and the climatic regime (NAKAwo \& RANA 1999).

Under the current climate change scenario, debris-covered glaciers are assuming a key biological role in high-altitude environments because they can host cold-adapted arthropod and plant species (CACCiAniga et al. 2011, GobBi et al. 2011, Hågvar et al. 2020). In fact, cold-adapted species may react to rising temperatures by finding refugium areas in glacial and periglacial landforms, as suggested for the Alps by Goввi et al. (2011, 2014, 2018). These landforms are defined "cold spots" of biodiversity, because glaciers host few species, which are, however, extremely specialised and exclusive (including many endemics), but currently threatened of extinction (CAUvY-FrauniÉ \& Dangles 2019, Gobbi \& Lencioni 2020). Together with the study of habitats acting as potential refugia for cold-adapted species, the knowledge of the ecological needs of climate-sensitive species in these cold habitats is fundamental to understand how climate change will affect Alpine biodiversity.

The ground beetle Nebria germari Heer, 1837 (Coleoptera: Carabidae) is a cold-adapted and hygrophilic species (BRANdMAYr \& ZETTo BRANDMAYr 1988, Gereben 1995, Kaufmann \& Juen 2001). It can be defined as a climate-sensitive species because it is currently restricted to high altitude habitats of the Eastern Alps, from Tessin, Switzerland, to the Prokletije Massif, Albania (Ledoux \& Roux 2005). This species also exhibits a fragmented distribution pattern (Ledoux \& Roux 2005), suggesting refugial occurrence, and local scale extinctions were already documented (Pizzolotтo et al. 2014). Moreover, N. germari is a brachypterous species with low dispersal ability and nocturnal foraging behaviour. High humidity and low temperatures are known to be the main environmental features affecting its distribution and abundance (BRANDMAYR \& Zetto Brandmayr 1988, Kaufmann \& Juen 2001, Pizzolotto et al. 2014). It prefers open grounds with low vegetation cover, and substrates with a high percentage of gravel (Brandmayr \& Zetto Brandmayr 1988, Kaufmann \& JuEn 2001). It lives on scree slopes, along glacier forelands, on rock glaciers and debris-covered glaciers (Kaufmann \& Juen 2001, Gereben et al. 2011, Gobвг et al. 2014, 2017). In these habitats, N. germari co-occurs with other grounddwelling arthropods; the most common on debris-covered glaciers being spiders (Arachnida: Araneae), springtails (Hexapoda, Collembola), and less frequently centipedes (Myriapoda: Chilopoda). Springtails are at the base of Nebria germari diet (SINT et al. 2019). Intraguild predation was demonstrated in arthropods living near the glacier fronts (KöNIG et al. 2011, RAso et al. 2014, Sint et al. 2019). Thus, we can hypothesise that the co-existence (sensu STAPLES 
et al. 2016) with spiders might affect the size of $N$. germari populations, particularly in glacier and near-glacier habitats. For instance, spiders may compete with $N$. germari in hunting activity: even if $N$. germari is primarily nocturnal and spiders are mainly diurnal, in this harsh environment $N$. germari activity was also documented during the day (GEREBEN 1995). Other competitors are centipedes, predators that in few cases were found in the same habitat of $N$. germari (unpublished data).

In this study, we aimed at describing the phenology and the current population dynamic of $N$. germari on supraglacial debris concerning both biotic (competitors and prey availability) and abiotic factors (micrometeorological conditions and soil gravel fraction). Besides, in order to investigate how global warming might affect this species, we compared our data on the present distribution of this species with those found in the literature to highlight possible ecological changes that have occurred in the last 60 year. Specifically, we focused on past and present altitudinal distribution of this species, which seems to respond to climate warming (Рizzolotтo et al. 2014), and its past and current phenology. Indeed, the timing of life-history events is crucial for insect species living in high altitude habitats, where the favourable season for the development, growth and reproduction lasts a few weeks (SотA 1996). We expect an upward shift in the distribution, and earlier phenology of this species in the present compared to past studies.

\section{MATERIAL AND METHODS}

\section{Study area}

We investigated three populations of Nebria germari located on three glaciers of the Dolomites (Italy): Western Sorapiss and Central Sorapiss Glaciers (46 $30^{\prime} 43.34^{\prime \prime}-12^{\circ} 12^{\prime}$ 25.12' and 46 $30^{\prime} 43.55^{\prime}-12^{\circ} 13^{\prime}$ 20.75' Ampezzo Dolomites) and Vedretta d'Agola Glacier $\left(46^{\circ} 9^{\prime} 6.29^{\prime \prime}-10^{\circ} 51^{\prime} 29.01^{\prime \prime}\right.$ Brenta Dolomites) (Fig. 1). In these sites, N. germari occurs almost exclusively on supraglacial debris, characterised by a vegetation cover always $<5 \%$ and consisting of sparse young individuals of pioneer plant species typical of carbonatic substrata of the alliance Thlaspion rotundifolii Jenny-Lips 1930, with only a very sporadic occurrence on the nearby moraines (BERNASCONi et al. 2019, VALLE 2019).

All these glaciers of the Dolomites are characterised by relatively low altitude and small surface (Table 1). Climatic features of the investigated areas were extrapolated from closely located weather stations (see micrometeorological analysis paragraph); average annual and monthly temperatures and average annual precipitations are reported in Tables 2 and 3.

During the fieldwork (2017-2018), data on the minimum altitude of glacier systems were collected, and the extent of the glaciers and the percentage of debris-covered surface were calculated using aerial photographs from 2015 (Table 1). Besides, debris thickness was estimated with different methods (Table 1). On Western and Central Sorapiss Glaciers debris thickness was measured digging the debris up to the ice along a regular grid 
Table 1. Altitude and surface characteristics of three glacial sites. Measurements at Agola were made in 2018, at Sorapiss in 2017. The extent of the glaciers and the degree of debris-covered surface were calculated using aerial photographs from 2015 and field data collected in 2017-2018.

\begin{tabular}{|c|c|c|c|c|c|c|c|}
\hline Glacier & $\begin{array}{l}\text { Type of } \\
\text { glacier }\end{array}$ & $\begin{array}{c}\text { Min } \\
\text { altitude } \\
(\mathrm{m} \text { asl) }\end{array}$ & $\begin{array}{l}\text { Max al- } \\
\text { titude } \\
(\mathrm{m} \text { asl) }\end{array}$ & $\begin{array}{l}\text { Sampling } \\
\text { altitude } \\
\text { (m asl) }\end{array}$ & $\begin{array}{l}\text { Sur- } \\
\text { face } \\
\left(\mathrm{km}^{2}\right)\end{array}$ & $\begin{array}{c}\text { Surface } \\
\text { covered by } \\
\text { debris, } \%\end{array}$ & $\begin{array}{l}\text { Estimated } \\
\text { debris thick- } \\
\text { ness }\end{array}$ \\
\hline Agola & $\begin{array}{l}\text { Active } \\
\text { moun- } \\
\text { tain } \\
\text { glacier }\end{array}$ & 2601 & 2873 & $\begin{array}{c}2596- \\
2603\end{array}$ & 0.17 & 1.2 & $10-15 \mathrm{~cm}$ \\
\hline $\begin{array}{l}\text { Western } \\
\text { Sorapiss }\end{array}$ & $\begin{array}{l}\text { Active } \\
\text { moun- } \\
\text { tain } \\
\text { glacier }\end{array}$ & 2254 & 2756 & $\begin{array}{c}2382- \\
2419\end{array}$ & 0.134 & 32 & $\begin{array}{c}>50 \mathrm{~cm} \text { at } 50 \% \\
\text { of measure- } \\
\text { ment points }\end{array}$ \\
\hline $\begin{array}{l}\text { Central } \\
\text { Sorapiss }\end{array}$ & $\begin{array}{l}\text { Inactive } \\
\text { glacier - } \\
\text { glacieret }\end{array}$ & 2213 & 2621 & $\begin{array}{c}2210- \\
2264\end{array}$ & 0.08 & 57.9 & $\begin{array}{l}>50 \mathrm{~cm} \text { at } 80 \% \\
\text { of measure- } \\
\text { ment points }\end{array}$ \\
\hline
\end{tabular}

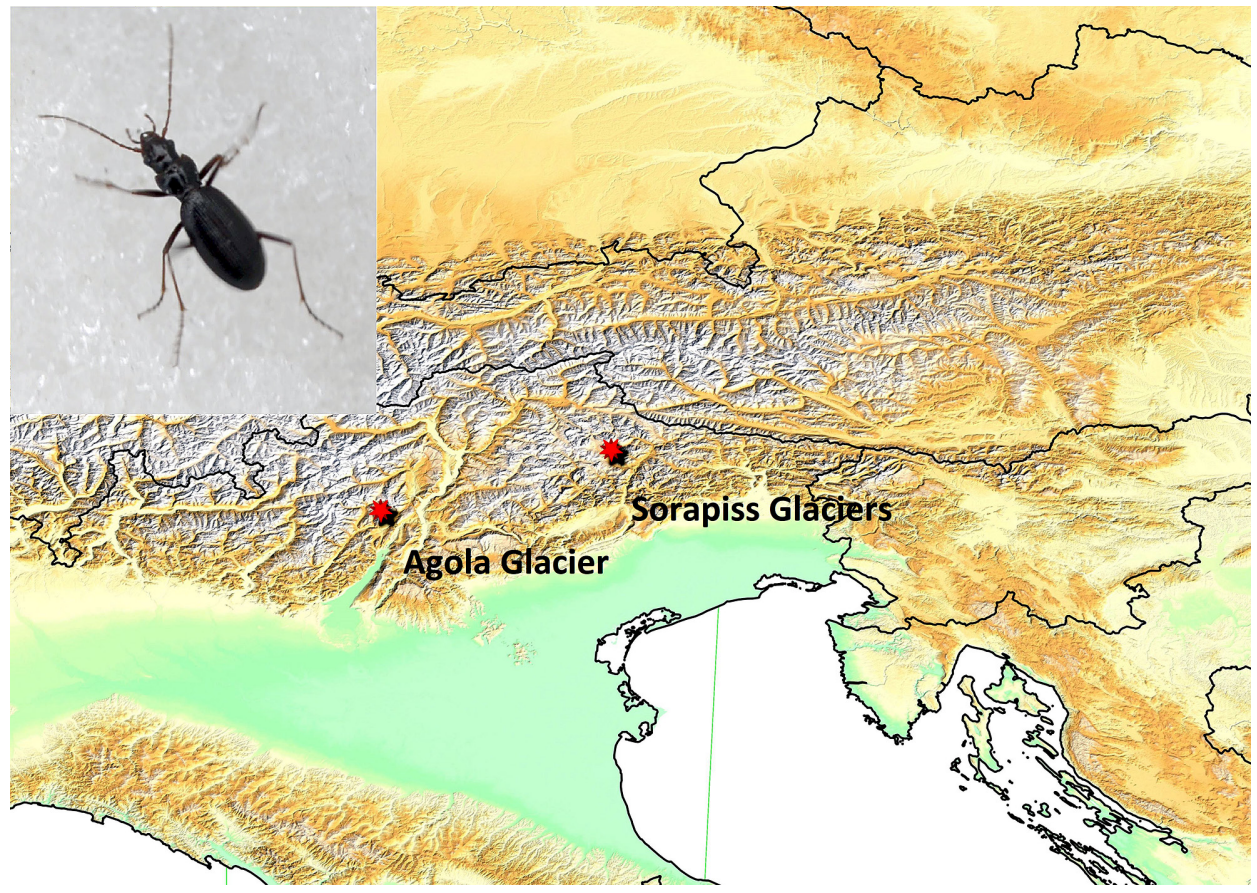

Fig. 1. Map with the position of the two sampling sites (Agola and Sorapiss). At the top left, a picture of N. germari taken on Sorapiss. (Photo by D. Dalpiaz and F. Pupin/ Archive MUSE) 
of points spaced $20 \mathrm{~m}$ to one another (29 points for Wester Sorapiss and 51 for Central Sorapiss, due to different size of the sampling areas). On Agola we measured the thickness around the traps because the use of a regular grid was impossible due to the small extent of the debris-covered part of the Glacier.

\section{Field procedures}

Sampling was carried out during the snow-free period of 2017 (Western and Central Sorapiss Glaciers) and of 2018 (Agola Glacier) by pitfall traps put on the supraglacial debris. Specifically, two plots were selected on Agola, two on Western Sorapiss and four on Central Sorapiss (two on the glacier and two on a dead-ice area separated from the glacier). Each plot was characterised by similar conditions in grain size distribution and vegetation cover (see the sampling plan in Appendix 1). Each plot consisted of three pitfall traps - spaced from each other by at least 10 meters. Pitfall traps consisted of a plastic glass (diameter $7 \mathrm{~cm}$ ) filled up with a non-toxic and frost-resistant solution to catch and preserve the animals during the activity period of the trap. The solution was made by one litre of water, $1 / 2$ litre of wine-vinegar, one tablespoon of salt and two-three drops of soap. This solution is slightly different from those used in similar studies (e.g. Gовв et al. 2017) and was used to reduce its attractive smell toward marmots (Marmota marmota) and alpine ibexes (Capra ibex), which are the most common vertebrates that damage the traps. Three sampling sessions were performed on Agola (6 August 2018 - 27 August 2018 - 18 September 2018), four on Western Sorapiss (5 July 2017 - 27 July 2017 - 17 August 2017 - 07 September 2017), three on Central Sorapiss (28 July 2017 - 18 August 2017 - 07 September 2017). Sampled specimens of $N$. germari were analysed at the stereomicroscope in order to distinguish them in three developmental stages: larva, teneral (i.e. newly hatched adults) and adult.

A sample of approximately $2 \mathrm{~kg}$ of soil was taken from each plot and used to estimate the grain size distributions by dry, wet sieving and aerometry.

Temperature and humidity (micro-meteorological variables hereafter), were recorded every 60 minutes on the supraglacial debris of each glacier by a datalogger (Tinytag plus 2), positioned $10 \mathrm{~cm}$ below the surface close to the plots (see Appendix 1). One datalogger was also placed on the recent moraine of 1908 (Agola) or 1920 (on Western and Central Sorapiss), respectively 500 and $200 \mathrm{~m}$ from the glacier front, to record the same variables on ice-free debris. Datalogger recording periods started from the beginning of the sampling period and were: 17 June 2018 - 02 June 2019 on Agola, 22 June 2017 - 21 August 2018 on Western Sorapiss, and 07 July 2017 - 22 August 2018 on Central Sorapiss.

\section{Analysis of micrometeorological data}

Day and night values were analysed separately because Nebria germari is known to be mainly a nocturnal predator (GEREBEN 1995). The average sunrise and sunset times for each month was used to assess day and night measures. The average annual temperature, the average day and the night summer temperature (mean of all daily day and night averages collected from the beginning of sampling period to the end of the snow-free season) were considered. Humidity was not recorded on Central Sorapiss because the humidity sensor was not available. Although we are aware that conditions can vary according to debris depth and grain size, we are confident that the data we collected are representative of the conditions of the sampling sites. 


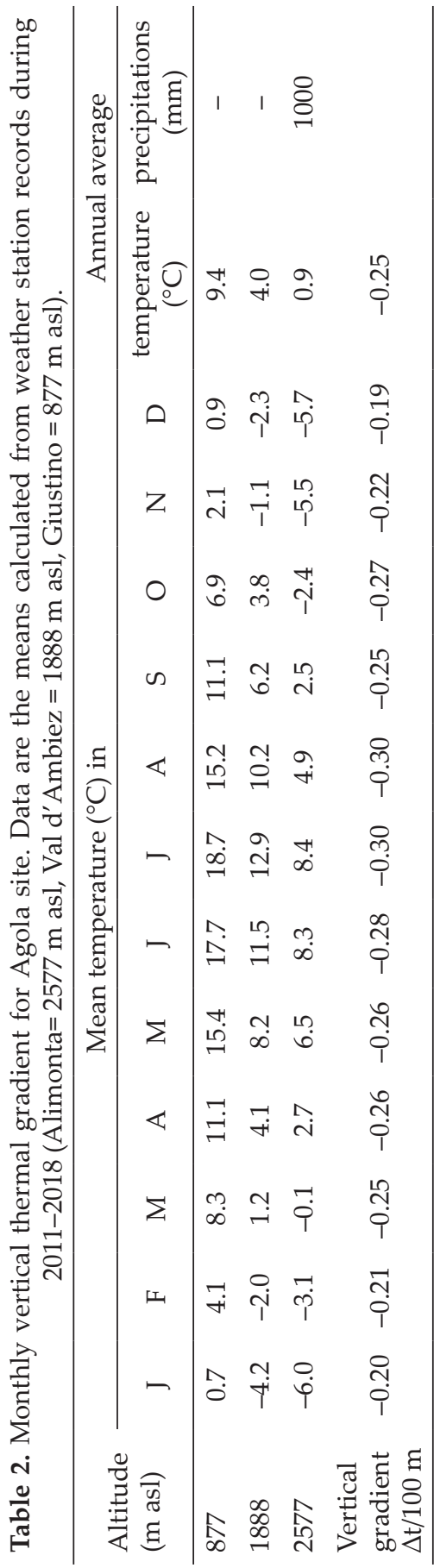

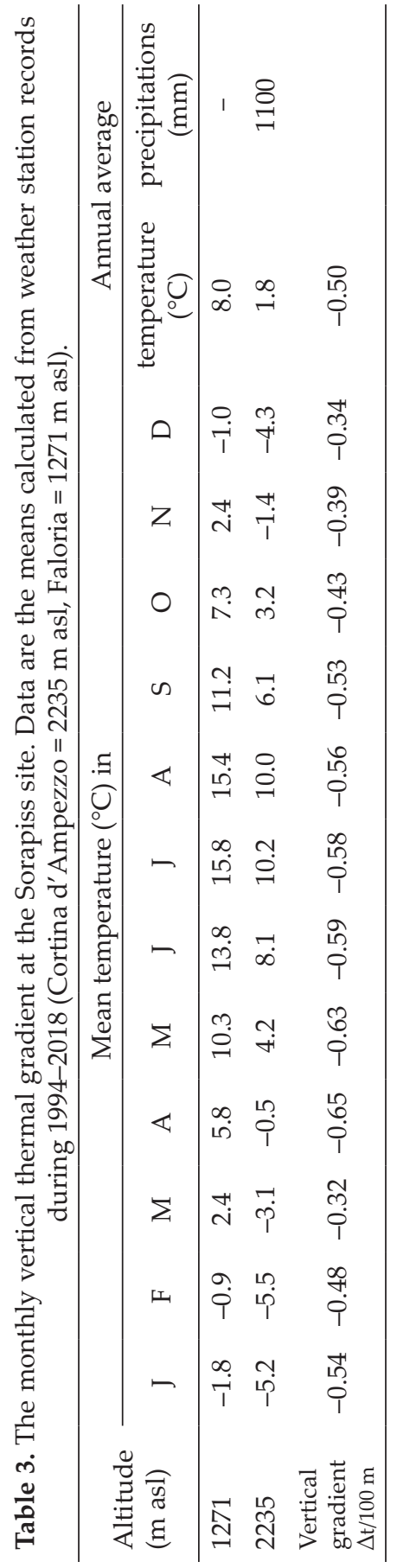


Supraglacial temperatures of each glacier were compared with values detected on the moraines of 1908/1920 and with atmospheric values calculated on the base of the data from the nearest weather stations with complete available data (Val d'Ambiez weather station for Agola Glacier, $1888 \mathrm{~m}$ asl, Trento Province, $3 \mathrm{~km}$ apart from the sampling site; Faloria weather station for Sorapiss Glaciers, $1743 \mathrm{~m}$ asl, Belluno Province, $4 \mathrm{~km}$ apart from the sampling site). In order to correctly compare datalogger and weather station values, which were recorded at different altitudes, we applied to weather station values a correction factor equal to the average vertical thermal gradient for each site and month (Tables $2,3)$. These correction factors were calculated for each site and month by linear interpolation of the data from weather stations located at different altitudes. For Agola Glacier, we used data from Meteotrentino weather stations of Alimonta refuge ( $2577 \mathrm{~m}$ asl, Trento Province), Val d'Ambiez (see above) and Giustino ( $877 \mathrm{~m}$ asl, Trento Province). Available data spanned 2011-2018. For Sorapiss, we used data from ARPA Veneto weather stations of Cortina d'Ampezzo (2335 m asl, Belluno Province) and Faloria (see above). Available data spanned the period 1994-2018.

\section{Ecological and phenological data analysis}

We considered the following information collected at each trap: days of trap activity, the absolute abundance of $N$. germari larvae, tenerals and adults, the absolute abundance of centipedes, springtails, adult spiders (sum of all Araneae taxa found: Acantholycosa spp., families Lyniphiidae and Thomisidae) and gravel percentage. We then used Generalised Linear Models (GLMs) assuming a Poisson data distribution to model the abundance of different $N$. germari developmental stages according to a set of predictors selected in agreement with the literature (see introduction), namely: day of the year $(1$ January $=1)$, gravel percentage, the abundance of centipedes and springtails (potential prey of N. germari), and abundance of spiders (potential predators/competitors of N. germari). A three-level factor indicating the glacier was also entered in the models together with the log10-transformed number of days for which a trap was active; the latter variable was entered as an offset to account for the difference in sampling effort. With this parameterisation, the GLM modelled the average number of individuals collected per day of trap activity. We also accounted for possible data overdispersion, which may inflate type-I error rate of the model, by using the family = quasipoisson option in R. Analyses were performed with R 3.6.2 ( R Core Team 2019).

\section{RESULTS}

A total of 138 individuals of Nebria germari were collected on Agola Glacier (51 larvae, 81 tenerals, 6 adults), 257 on Western Sorapiss Glacier (51 larvae, 9 tenerals, 197 adults) and 444 on Central Sorapiss Glacier (104 larvae, 82 tenerals, 258 adults). The average activity density (AD: number of collected individuals per day of trap activity) of all N. germari (larvae, adults and tenerals) recorded on each glacier during the whole sampling periods was higher on Sorapiss glaciers $(0.64 \pm 0.64$ on Western Sorapiss and $0.64 \pm 0.41$ on Central Sorapiss) than on Agola glacier (0.38 \pm 0.45$)$. 
Table 4. Mean annual temperatures $( \pm$ S.D. $)$, mean temperatures $( \pm$ S.D. $)$ during the snowfree period and length of the snow-free period on the supraglacial debris. Period 2017-2018.

\begin{tabular}{|c|c|c|c|c|}
\hline \multirow[t]{2}{*}{ Location } & \multirow{2}{*}{$\begin{array}{c}\text { Mean annual } \\
\text { temperature }\left({ }^{\circ} \mathrm{C}\right)\end{array}$} & \multicolumn{2}{|c|}{$\begin{array}{l}\text { Mean temperature during } \\
\text { snow-free period }\left({ }^{\circ} \mathrm{C}\right)\end{array}$} & \multirow{2}{*}{$\begin{array}{l}\text { Snow-free pe- } \\
\text { riod (days) }\end{array}$} \\
\hline & & Daytime & Nighttime & \\
\hline Western Sorapiss & $-0.2 \pm 2.8$ & $2.8 \pm 2.7$ & $2.9 \pm 2.7$ & 130 \\
\hline Central Sorapiss & $-0.8 \pm 1.4$ & $1.1 \pm 1.6$ & $0.8 \pm 1.2$ & 105 \\
\hline
\end{tabular}

\section{Temperature and humidity}

We estimated the duration of the snow cover from the daily trend of day and night temperatures (see Appendix 2). The beginning of snow cover is indicated by a monotonous decreasing trend of daily temperatures. This occurred on October 28th on Agola Glacier and on November 6th on Sorapiss Glaciers. The long spring plateau at $0{ }^{\circ} \mathrm{C}$ indicates that melting was occurring. The end of this plateau indicates the beginning of the snow-free period. On Western Sorapiss snow completely melted by June 30th, on Central Sorapiss by July 25th. The datalogger on Agola Glacier did not record data from 3 July 2019 to 16 June 2019. To estimate the beginning of snow-free season at this site. We, therefore, used data collected by the datalogger placed on the 1908 moraine to estimate the beginning of the snow-free period. On the moraine snow melted on June 30th. Thus, on supraglacial debris this happened between 30 June 2019 and 16 June 2019 (the end of missing data period). We used these data to calculate thermal conditions linked to our sampling period, reported in Table 4; for Agola Glacier it was not possible due to missing data for June and July.

Day temperature during the snow-free period was almost equal to (on Sorapiss) night temperature (Table 4).

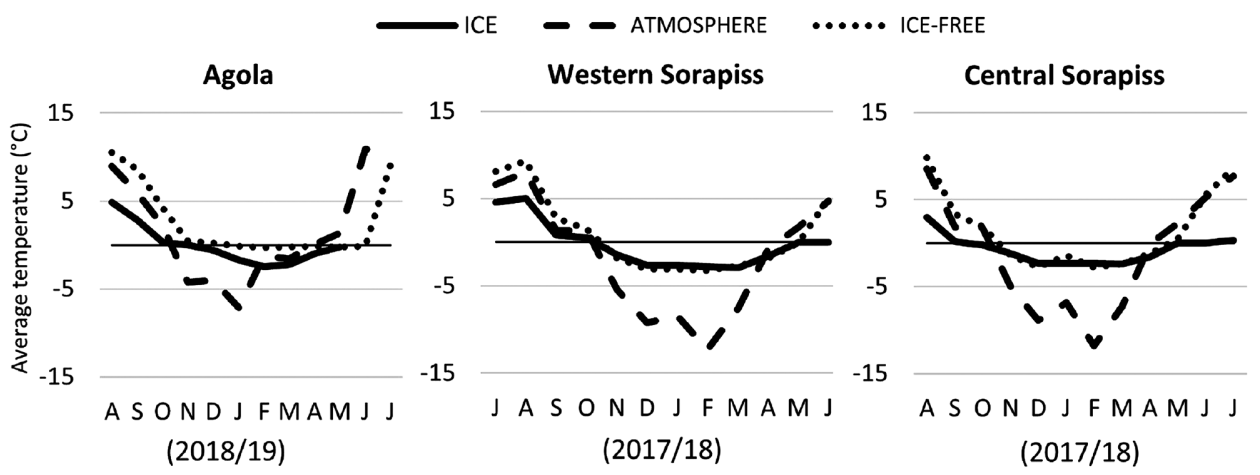

Fig. 2. Monthly temperatures on supraglacial debris, ice-free debris and atmosphere. 
In Figure 2, monthly temperature trends on supraglacial debris, on icefree debris and in the atmosphere, are reported for each glacier (values are reported in Appendix 3). Supraglacial habitat showed colder condition than the atmosphere and the ice-free debris during summer and warmer conditions than the atmosphere during winter. The annual average temperature of supraglacial debris is always lower than that of ice-free debris and atmosphere. However, each datalogger showed different values, probably because of the different thickness and porosity of the supraglacial debris.

Maximum recorded values were: $16^{\circ} \mathrm{C}$ on Agola (23/VII/2018), $10.2{ }^{\circ} \mathrm{C}$ on Western Sorapiss (07/VII/2017) and $6.9^{\circ} \mathrm{C}$ Central Sorapiss (20/VII/2017). All daily values of day and night humidity are reported in Appendix 4. Missing data are due to the reset of the sensor when it remains saturated of water for a long time. On the glacier, air under the surface showed high levels of relative humidity, with an average daily humidity of $94 \%$ with almost no difference between the day and night values.

\section{Ecological and phenological data analysis with GLM}

The abundance of the different developmental stages at each sampling session and glacier is shown in Figure 3. Abundance of both larvae and subadults increased with day-of-year (larvae: coef. $=0.03 \pm 0.01 \mathrm{SE}, \mathrm{F}_{1,64}=9.10, \mathrm{P}=$ 0.004; subadults: coef. $\left.=0.04 \pm 0.01 \mathrm{SE}, \mathrm{F}_{1,64}=10.13, \mathrm{P}=0.002\right)$, while that of adults decreased along the season (coef. $=-0.04 \pm 0.01 \mathrm{SE}, \mathrm{F}_{1,64}=43.90, \mathrm{P}<0.001$ ).

Abundance of larvae did not differ among glaciers $\left(\mathrm{F}_{2,64}=0.66, \mathrm{P}=0.528\right)$, There was a tendency toward differences in overall abundances of subadults among glaciers $\left(\mathrm{F}_{2,64}=3.54, \mathrm{P}=0.035\right)$; however, Tukey post-hoc tests failed in

- Larvae $\mathbb{\text { m Tenerals }}$ adults
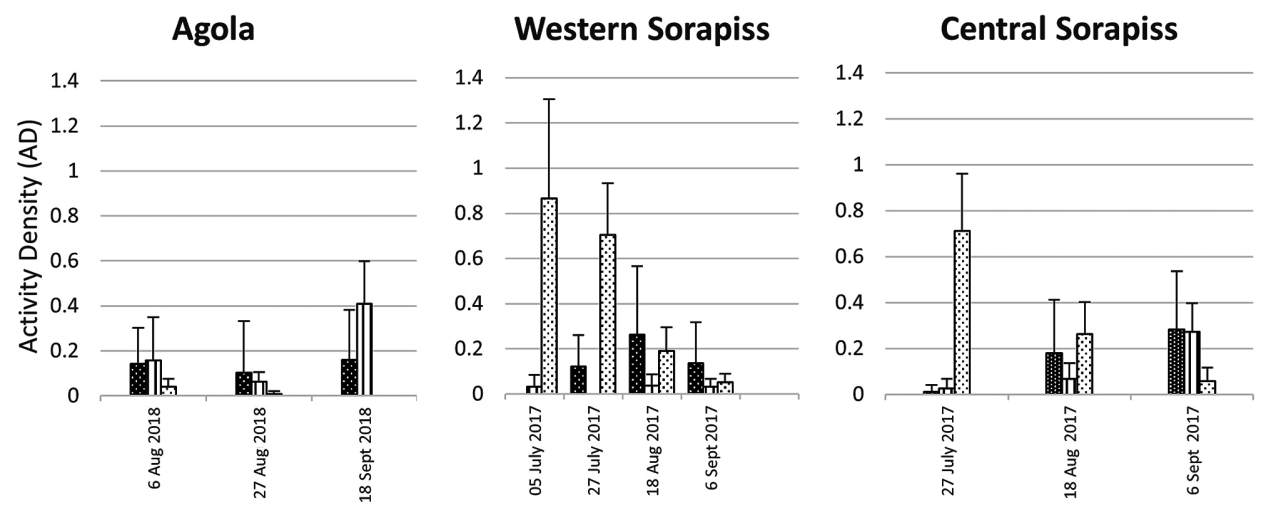

Fig. 3. Sampling data are expressed as average Activity Density (AD: number of individuals per day of trap activity). Whiskers represent standard deviation 
detecting any pairwise difference between glaciers ( $|z| \leq 2.04, P \geq 0.095)$. In contrast, abundance of adults was significantly lower on Agola glacier than on both Sorapiss glaciers $\left(\mathrm{F}_{2,64}=9.62, \mathrm{P}<0.001\right.$, post-hoc tests: $\left.|\mathrm{z}| \geq 2.71, \mathrm{P} \leq 0.016\right)$, which did not differ to one another $(\mathrm{z}=0.73, \mathrm{P}=0.728)$.

Abundance of the different life-stages was also affected by different ecological variables of sampling sites. As shown by the GLM analysis, larvae abundance increased with increasing abundance of centipedes (coef: $0.06 \pm 0.02$ $\mathrm{SE}, \mathrm{F}_{1,64}=8.15, \mathrm{P}=0.006$ ), teneral abundance decreased with increasing number of spiders (coef: $-0.57 \pm 0.27 \mathrm{SE}, \mathrm{F}_{1,64}=6.14, \mathrm{P}=0.016$ ), adult abundance decreased at increasing gravel percentages (coef. $=-5.10 \pm 1.44 \mathrm{SE}, \mathrm{F}_{1,64}=13.22$, $\mathrm{P}<0.001$. All the other effects were not significant $\left(\mathrm{F}_{1,64} \leq 2.54, \mathrm{P} \geq 0.115\right)$.

\section{DISCUSSION}

Data collected on the investigated glaciers of the Dolomites provided the first evidence about the micrometeorological features of the supraglacial habitats inhabited by N. germari. Besides, they allowed us to describe population patterns in time and in relation to potential competitors and prey availability.

\section{Micrometeorological conditions}

Micrometeorological data gave detailed information about the cold conditions characterising supraglacial debris where N. germari currently lives. The recorded annual average temperatures always spanned between $-1{ }^{\circ} \mathrm{C}$ and $0{ }^{\circ} \mathrm{C}$. These data is in agreement with those recorded on the debris cover of Amola Glacier (Presanella Group, Central-Eastern Alps; Gовві et al. 2017) suggesting similar thermal properties notwithstanding different lithology (tonalite, an igneous intrusive rock) of the debris of this latter glacier. Average temperatures recorded in the supraglacial habitat were similar or slightly lower than those on the adjacent ice-free debris, but always higher than those estimated for the atmosphere during winter, as an effect of the snow cover, and lower than both them during summer, probably as a direct effect of the presence of ice. Temperatures were almost identical during day and night, but this also occurred on the glacier forelands. Thus, temperature homogeneity between day and night is not due to the presence of ice, since it is not an exclusive feature of supraglacial environment, but probably to the thermal inertia of stony debris. Other essential features recorded on supraglacial debris are the low annual temperature excursions and the quite constant high level of humidity, an important condition for a species like N. germari that lives where the soil is drenched of water, as observed by BRANDMAYR and ZeTTo BRANDMAYR (1988). Thus, the micrometeorological conditions in the extreme 
environment of the debris cover of glacier are more stable than those of the close ice-free debris, and therefore probably more suitable for this species.

Literature data reported that $N$. germari lives only in drenched soils, but little is known about the influence of temperature on its activity. Indeed, a study performed on the Rocky Mountains by Slatyer and Schoville (2016) demonstrated that cold and heat tolerances vary little among Nebria species along an elevation gradient, and these variations are not generally associated with species turnover; in particular, heat tolerance of adults spans between $32.2^{\circ} \mathrm{C}$ and $37.0^{\circ} \mathrm{C}$. Even if our dataloggers registered maximum hourly peak of $16^{\circ} \mathrm{C}$ on Agola, $10.2{ }^{\circ} \mathrm{C}$ on Western Sorapiss and $6.9^{\circ} \mathrm{C}$ on Central Sorapiss, Gовві et al. (2017) found that temperatures in other sites where N. germari lives (Amola glacier) can reach up to $30^{\circ} \mathrm{C}$. This information suggests that $N$. germari adults might survive at higher temperatures like those found by SLATYER and Schoville (2016). As suggested by Hågvar et al. (2017) for Norwegian alpine ground beetles, the ecology of larvae and their temperature preferences could be the key element determining alpine Nebria survival and habitat choice (Thiele 1972). Personal observations on Alpine glaciers highlighted that occurrence of $N$. germari larvae is higher at the ice-debris interface, where debris pressure melts the ice, which is the place where their prey (springtails) occur at high density. Therefore, we hypothesised that larvae might represent the stage of Nebria development that is more linked to the presence of ice. Low temperatures of supraglacial debris could also influence biotic factors related to interspecific interactions (SLATYER \& SChoville 2016), for example reducing the predation pressure on larvae due to the absence of other predators, as proposed by CURRIE et al. (1996). However, heat tolerance of N. germari's adults and larvae still needs to be assessed in the laboratory to confirm these hypotheses.

\section{Phenology}

Our results show that $N$. germari adults are abundant at the beginning of the snow-free period, and then progressively decrease during summer. Larvae found during the snowmelt period (early July) develop during summer (July-September), resulting in the increase of tenerals observed in late season (August-September). During our first sampling session on Agola Glacier, we collected a low number of adults and proportionally more larvae than on the other glaciers, suggesting that on that glacier, larvae development had started already; the lack of early adults, which are the most abundant developmental stage on Sorapiss Glaciers, may explain the generally lower numbers on Agola Glacier. Our data suggest that N. germari can be considered a spring breeder: the reproduction seems to start at the very beginning of the snow- 
free period (end of June - early July), and larvae develop during the following months, from July to September at least (the date of our last sampling). These observations differ from those of BRANDMAYR and ZetTo BrANDMAYR (1988), who reported that $N$. germari was an autumn breeder, at least for the populations found in high alpine carbonate discontinuous grasslands. However, our observations are consistent with KAUfMANN and Juen's (2001) observations on a pioneer habitat on an Austrian glacier. Previous studies, therefore, support evidence of differences in breeding time on alpine grasslands concerning glacier forelands and glaciers surface. We stress, however, that species inhabiting alpine habitats usually reproduce during the short snow-free period. Therefore the dichotomy between spring and autumn breeder may have little ecological relevance since breeding period only spam from July to September (Sota 1996).

Our dataloggers allowed estimating a very short snow-free period (121 days on Agola, 130 days on Western Sorapiss, 105 days on Central Sorapiss). A long persistence of the snow cover is a constant of $N$ germari's habitat (BRANDmayr \& Zetto Brandmayr 1988, Gereben, 1995). Overwintering larvae and a biennial life-cycle are key adaptive features to high alpine environments characterised by a very short snow-free season (SotA 1996, ANDERSEN 1984). Both these features are already known for N. germari (DE ZoRdo 1979, BRANDmayr \& Zetto Brandmayr 1988, Kaufmann \& Juen 2001) and are consistent with our observations. Indeed, both the large number of larvae and tenerals found at the end of the snow-free season and the abundance of adults immediately after snowmelt (also reported by GEREBEN, 1995) suggest that also supraglacial populations have overwintering larvae and probably a biennial life-cycle. However, it is still unknown if $N$. germari larvae enter diapause or remain active during winter. Indeed, even winter could potentially be a favourable growing season for $N$. germari, because environmental conditions are stable under the snow cover, and food may be available, due to cold-hardiness of Collembola. These features may allow either winter activity or dormancy (Vanin \& Turchetto 2007, Block \& Zettel 1980, Sømme 1981, Woude \& VERHOEF 1988). Which overwintering strategy is actually used by N. germari should therefore be tested in laboratory conditions.

\section{Responses to ecological factors}

GLM analysis supports the evidence that different life-stages respond to different predictors; this is reasonable if we consider that larvae have lower mobility (HÅGVAR et al. 2017) and a different vertical distribution than adults and tenerals (Kaufmann \& Juen 2001). Besides, larvae and tenerals may be more vulnerable to predation than adults because of the less sclerotised exoskeleton. 
Adults density on the supraglacial debris was significantly related to grain size distribution; in particular, the gravel fraction was negatively related to $N$. germari adult abundance probably because of a lower detection probability where grain size is greater as suggested by TENAN et al. (2016).

Teneral abundance was negatively related to spider abundance, maybe because of intraguild predation of spiders on teneral ground beetles. Differently from larvae that live deep in the debris, and adults that have a thicker exoskeleton, tenerals have a soft exoskeleton and inhabit the surface, probably experiencing a higher predatory pressure. Alternatively, this association may be spurious and related to independent temporal trends of N. germari tenerals and spiders. The very similar temperatures during day and night allow hypothesising that $N$. germari could be active even during the day in the supraglacial habitat, thus being huntable by the spiders. The abundance of larvae was positively related to that of centipedes even if they are both predators, probably because they co-occur in the same site where food is abundant. Indeed, they share similar edaphic needs and they probably live at the same depth. However, it should be considered that centipedes are very few (only 5 specimens on Agola and 4 on Central Sorapiss). In order to fully understand the interactions of Nebria germari with other predators, direct observations in the field and gut content analysis are therefore necessary (RAso et al. 2014, Sint et al. 2019).

Contrary to our expectations, we found no significant relation between $N$. germari density and springtail abundance. Springtails were often very abundant in our samples, particularly those belonging to the genus Orchesella that can represent an ideal prey for $N$. germari. We hypothesised that the lack of relation could be due to a generally large abundance of surface-active springtails on the supraglacial debris, which therefore does not constitute a limiting factor for N. germari.

\section{Changes in altitudinal distribution}

$N$. germari seems to have moved to the higher altitude, probably as a consequence of climate change. Indeed, previous works (MARCUZzI 1956, BRANDmayr \& Zetto Brandmayr 1988, Pizzolotto et al. 2014) reported that, until the second half of the last century, the lower altitudinal limit of $N$. germari in the Dolomites was around $2000 \mathrm{~m}$ asl. Specifically, the species was found in discontinuous alpine grasslands on carbonate substrata dominated by Carex firma. Field data collected in the last thirty years on the Paneveggio-Pale di San Martino Dolomites (Pızzolotro et al. 2014) demonstrated the current extinction in this grassland type of the Southern Alps and an altitudinal shift of 300 meters about 30 years (1980-2008/09), with a consequent contraction of the distribution range. Our observations confirm the absence of this species 
from alpine grassland and the migration to more pioneer communities. In particular, we observed N. germari only on the supraglacial debris (excluding sporadic catches on the nearby glacier foreland; BERNAsconi et al. 2019, VALLE 2019).

The minimum altitude in which this species occurs in the studied areas is currently $2598 \mathrm{~m}$ asl on Agola (Brenta Dolomites), $2264 \mathrm{~m}$ asl on Western Sorapiss, $2168 \mathrm{~m}$ asl on Central Sorapiss (Ampezzo Dolomites). In order to calculate the altitudinal shifts, we compared our data with historical work of Marcuzzi (1956) and with Marcuzzi's Collections preserved at Natural History Museum of Genova (10 specimens; sampling year: 1972) for Ampezzo Dolomites and with MUSE - Science Museum's collections (15 specimens; sampling years: from 1935 to 1942) for Brenta Dolomites. The average altitudinal shift occurred in cc. 60 years was of cc. $210 \mathrm{~m}$ in Ampezzo Dolomites (1956-2017; cc. $260 \mathrm{~m}$ in Western Sorapiss and $170 \mathrm{~m}$ in Central Sorapiss) and of cc. $500 \mathrm{~m}$ in about 80 years in Brenta Dolomites (1939-2018).

\section{Alpine refugia}

In the last decades, the key biological role of debris-covered glaciers has been recognised. Indeed, this habitat is hosting cold-adapted arthropod species during the current interglacial period (Gоввi et al. 2011, 2018, HÅgvar et al. 2020). The Dolomites are particularly sensitive to the effects of climate change because of their relatively low altitude and the small size of their glaciers, which are undergoing a shrinking of surface size and an increase in debris cover that could partially reduce melting rate (NAKAwo \& RANA 1999). Here, N. germari, currently finds a suitable habitat only on the supraglacial debris, that persists at different altitudes depending on the glacier morphology and the degree of debris cover (Pelfini et al. 2012): on Central Sorapiss the debris cover $70 \%$ of the glacier surface and protect the ice from melting even at an altitude as low as $2213 \mathrm{~m}$ asl. Here we observed the minimum altitudinal shift in N. germari distribution.

We found that glacier debris cover (of both active and inactive glaciers, like Central Sorapiss) has peculiar micrometeorological features that make this habitat a perfect refugium for a cold-adapted hygrophile species like $N$. germari during the current interglacial period. However, depending on the climatic regime, different landforms can assume the same role (TAMPUCCI 2017): in more continental and cold climates rock glaciers can persist at lower altitudes than debris-covered glacier, and can provide an ideal refuge also for subterranean species, because they are characterised by a thickness of the debris that can exceed $6 \mathrm{~m}$ with a considerable fissure network among boulders, which can include human-sized caves (Gовві et al. 2014). 
The first satellite mapping of supraglacial debris of glacial and periglacial landform was provided by SCHERLER et al. (2018) and allowed estimating that the extent of N. germari potential habitat in Eastern Alps is $555 \mathrm{~km}^{2}$, but extremely discontinuous and fragmented. This habitat is currently expanding, providing refuge to cold-adapted species. However, we do not know how long these landforms will last if the climate continues to warm. The risk of a complete loss of suitable habitats for this species is exacerbated by the fact that $N$. germari is present in Dolomites with the steno-endemic subspecies simony Ganglbauer, 1892; thus, its extinction in the Alps will cause an essential loss for this "cold spot" of biodiversity.

Acknowledgements - We thank Michael Bernasconi, Marina Serena Borgatti and Marta Tognetti for the key support during sampling sessions. We also thank Ampezzo Dolomites Natural Park and the Adamello-Brenta Natural Park for permission for carrying out this research.

\section{REFERENCES}

Andersen, J. (1984): A re-analysis of the relationship between life cycle patterns and the geographical distribution of Fennoscandian carabid beetles. - Journal of Biogeography 11: 479-489. https://doi.org/10.2307/2844794

Bernasconi, M. G., Borgatti, M. S., Tognetti, M., Valle, B., Caccianiga, M., Casarotto, C., BAllarin, F. \& GobBI, M. (2019): Checklist ragionata della flora e degli artropodi (Coleoptera: Carabidae e Arachnida: Aranae) dei ghiacciai Centrale e Occidentale del Sorapiss (Dolomiti d'Ampezzo). - Frammenti, conoscere e tutelare la natura bellunese 9: 49-65

Block, W. \& Zettel, J. (1980): Cold hardiness of some alpine Collembola. - Ecological Entomology 5: 1-9. https://doi.org/10.1111/j.1365-2311.1980.tb01118.x

Brandmayr, P. \& Zetto Brandmayr, T. (with collaboration of Pizzolotto, R.) (1988): Comunità a Coleotteri Carabidi delle Dolomiti Sudorientali e delle Prealpi Carniche. - Studi Trentini Scienze Naturali, Acta Biologica 64(Suppl.): 125-250.

Caccianiga, M., Andreis, C., Diolaiuti, G., D’Agata, C., Mihalcea, C. \& Smiraglia, C. (2011): Alpine debris-covered glaciers as a habitat for plant life. - The Holocene 21(6): 1011-1020. https://doi.org/10.1177/0959683611400219

Cauvy-Fraunié, S. \& Dangles, O. (2019): A global synthesis of biodiversity responses to glacier retreat. - Nature Ecology \& Evolution 3: 1675-1685. https:/doi.org/10.1038/ s41559-019-1042-8

Citterio, M., Diolaiuti, G., Smiraglia, C., D’Agata, C., Carnielli, T., Stella, G. \& SiLETTO, G. B. (2007): The fluctuations of Italian glaciers during the last century: a contribution to knowledge about Alpine glacier changes. - Geografiska Annaler 89A(3): 167-184. https://doi.org/10.1111/j.1468-0459.2007.00316.x

Currie, C. R., Spence, J. R. \& Niemelë, J. (1996): Competition, cannibalism and intraguild predation among ground beetles (Coleoptera: Carabidae): A laboratory study. - Coleopterists Bulletin 50: 135-148. 
DE Zordo, I. (1979): Phänologie von Carabiden im Hochgebirge Tirols (Obergurgl, Österreich) (Insecta: Coleoptera). - Berichte des Naturwissenschaftlich-medizinischen Vereins in Innsbruck 66: 73-83.

Fattorini, S., Mantoni, C., Di Biase, L. \& Pace, L. (2020): Mountain biodiversity and sustainable development. Pp. 1-21. In: Leal Filho, W., Azul, A., Brandli, L., Lange SalVIA, A. \& WALL, T. (eds): Life on land. Encyclopedia of the UN Sustainable Development Goals. - Springer, Cham. https://doi.org/10.1007/978-3-319-71065-5_144-1

Gentili, R., Baroni, C., Caccianiga, M. Armiraglio, S. Ghiani, A. \& Citterio, S. (2015): Potential warm-stage microrefugia for alpine plants: Feedback between geomorphological and biological processes. - Ecological Complexity 21: 87-99. https://doi. org/10.1016/j.ecocom.2014.11.006

Gereben, B. (1995): Co-occurrence and microhabitat distribution of six Nebria species (Coleoptera: Carabidae) in an alpine glacier retreat zone in the Alps, Austria. - Arctic and Alpine Research 27(4): 371-379. https://doi.org/10.2307/1552030

Gereben-Krenn, B.-A., Krenn, H. \& Strodl, M. (2011): Initial colonisation of new terrain in an alpine glacier foreland by carabid beetles (Carabidae, Coleoptera). - Arctic, Antarctic and Alpine Research 43: 397-403. https://doi.org/10.1657/1938-4246-43.3.397

Gobbi, M., De Bernardi, F., Pelfini, M., Rossaro, B. \& Brandmayr P. (2006): Epigean arthropod succession along a 154-year Glacier Foreland Chronosequence in the Forni Valley (Central Italian Alps). - Arctic, Antarctic, and Alpine Research 38(3): 357-362. https://doi.org/10.1657/1523-0430(2006)38[357:EASAAY]2.0.CO;2

Gobbi, M., Isaia, M. \& De Bernardi, F. (2011): Arthropod colonisation of a debris-covered glacier. - The Holocene 21(2): 343-349. https://doi.org/10.1177/0959683610374885

Gobbi, M., Ballarin, F., Compostella, C., Lencioni, V., Seppi, R., Tampucci, D. \& CaCCIANIGA M. (2014): Physical and biological features of an active rock glacier in the Italian Alp. - The Holocene 24(11): 1624-1631. https://doi.org/10.1177/0959683614544050

Gobbi, M., Ballarin, F., Brambilla, M., Compostella, C., Isaia, M., Losapio, G., MaffioLetTi, C., Seppi, R., Tampucci, D. \& Caccianiga, M. (2017): Life in harsh environments: carabid and spider trait types and functional diversity on a debris-covered glacier and along its foreland. - Ecological Entomology 42: 838-848. https://doi.org/10.1111/een.12456

Gobbi, M. \& Lencioni, V. (2020): Glacial biodiversity: Lessons from ground-dwelling and aquatic insects. - IntechOpen. https://doi.org/10.5772/intechopen.92826

Gobbi, M., Tampucci, D. \& Caccianiga, M. (2018): Appena scoperta, già minacciata: Oreonebria soror tresignore Szallies \& Huber, 2014 (Coleoptera, Carabidae). - Rivista del Museo Civico di Scienze Naturali "Enrico Caffi" 31: 3-10.

HÅgvar, S., STEEN, R. \& FLø, D. (2017): Ecology of alpine carabid beetles (Coleoptera, Carabidae) in a Norwegian glacier foreland, with a special focus on claw wearing to indicate relative age. - Norwegian Journal of Entomology 64: 82-111.

Hågvar, S., Gobbi, M., Kauffmann, R., Ingimarsdóttir, M., Caccianiga, M., Valle, B., Pantini, P., Fanciulli, P. P. \& Vater, A. (2020): Ecosystem birth near melting glaciers: A review on the pioneer role of ground-dwelling arthropods. - Insects 11: 644. https://doi.org/10.3390/insects11090644

Hodkinson, D. I. (2005): Terrestrial insects along elevation gradients: species and community responses to altitude. - Biological Review 80: 489-513. https://doi.org/10.1017/ S1464793105006767

Kaufmann, R. \& Juen, A. (2001): Habitat use and niche segregation of the genus Nebria (Coleoptera: Carabidae) in the Austrian Alps. - Mitteilungen der Schweizerischen Entomologischen Gesellschaft 74: 237-254. 
König, T., Kaufmann, R. \& Scheu, S. (2011): The formation of terrestrial food webs in glacier foreland: evidence for the pivotal role of decomposer prey and intraguild predation. - Pedobiologia 54: 147-152. https://doi.org/10.1016/j.pedobi.2010.12.004

KraAjienbrink, P., Bierkens, M., Lutz, A. \& Immerzeel, W. W. (2017): Impact of a global temperature rise of 1.5 degrees Celsius on Asia's glaciers. - Nature 549: 257-260. https://doi.org/10.1038/nature23878

Ledoux, G. \& Roux, P. (2005): Nebria (Coleoptera, Nebriidae): Faune mondiale. - Muséeum, Département du Rhône, 789 pp.

Marcuzzi, G. (1956): Fauna delle Dolomiti. - Ist. Veneto di Scienze, Lettere ed Arti, 549 pp.

NaKAwO, M. \& RANA, B. (1999): Estimation of ablation rate of glacier ice under a supraglacial debris layer. - Geografiska Annaler: Series A, Physical Geography 81A(4): 695-701. https://doi.org/10.1111/1468-0459.00097

Paul, F., KäÄв, A. \& Haberli, W. (2007): Recent glacier changes in the Alps observed by satellite: consequences for the future monitoring strategies. - Global and Planetary Change 56: 111-122. https://doi.org/10.1016/j.gloplacha.2006.07.007

Pelfini, M., Diolaiuti, G., Leonelli, G., Bozzonio, M., Bressan, N., Brioschi, D. \& RiccaRDI, A. (2012): The influence of glacier surface processes on the short-term evolution of supraglacial tree vegetation: the case study of Miage Glacier, Italian Alps. - The Holocene 22(8): 847-856. https://doi.org/10.1177/0959683611434222

Pizzolotto, R., Gobbi, M. \& Brandmayr, P. (2014): Changes in ground beetle assemblages above and below the treeline of the Dolomites after almost 30 years (1980/2009). Ecology and Evolution 4(8): 1284-1294. https://doi.org/10.1002/ece3.927

R Core Team (2019): R: A language and environment for statistical computing. - Foundation for Statistical Computing, Vienna. https://www.R-project.org

Raso, L., Sint, D., Mayer, R., Plangg, S., Recheis, T., Brunner, S., Kaufmann, R. \& TrauGOTT, M. (2014): Intraguild predation in pioneer predator communities of alpine glacier forelands. - Molecular Ecology 23(15): 3744-3754. https://doi.org/10.1111/mec.12649

SCHERLER, D., WUlF, H. \& Gorelick, N. (2018): Global assessment of supraglacial debris-cover extents. - Geophysical Research Letters 45(11): 798-805. https://doi.org/10.1029/2018GL080158

Sint, D., Kaufmann, R., Mayer, R. \& Traugott, M. (2019): Resolving the predator first paradox: Arthropod predator food webs in pioneer sites of glacier forelands. - Molecular Ecology 28: 336-347. https://doi.org/10.1111/mec.14839

Slatyer, R. A. \& Schoville, S. D. (2016): Physiological limits along an elevational gradient in a radiation of montane ground beetles. - PLOS ONE 11(4): e0151959. https://doi. org/10.1371/journal.pone.0151959

SотA, T. (1996): Altitudinal variation in life cycles of carabid beetles: Life-cycle strategy and colonisation in alpine zones. - Arctic and Alpine Research 28: 441-447. https://doi. org/10.2307/1551855

Søмме, L. (1979): Overwintering ecology of alpine Collembola and oribatid mites from the Austrian Alps. - Ecological Entomology 4: 175-180. https://doi.org/10.1111/j.1365-2311.1979. tb00572.x

Søмme, L. (1981): Cold tolerance of alpine, arctic, and Antarctic Collembola and mites. Cryobiology 18: 212-220. https://doi.org/10.1016/0011-2240(81)90091-2

Staples, T. L., Dwyer, J. M., Loy, X. \& Mayfield, M. M. (2016): Potential mechanisms of coexistence in closely related forbs. - Oikos 125(12): 1812-1823. https://doi.org/10.1111/ oik.03180

TAmpucci, D. (2017): Periglacial and glacial landforms as warm-stage refugia for cold-adapted plant and arthropod species. - PhD Thesis, University of Milan, 215 pp. 
Tenan, S., Maffioletti, C., Caccianiga, M., Compostella, C., Seppi, R. \& Gobbi, M. (2016): Hierarchical models for describing space-for-time variations in insect population size and sex-ratio along primary succession. - Ecological Modelling 329: 18-19. https://doi. org/10.1016/j.ecolmodel.2016.02.006

Thiele, H. U. (1977): Carabid beetles in their environments: a study on habitat selection by adaptations in physiology and behaviour. - Springer-Verlag, Berlin, $372 \mathrm{pp}$.

Tielidze, L. G., Bolch, T., Wheate, R. D., Kutuzov, S. S., Lavrentiev, I. I. \& Zemp, M. (2020): Supra-glacial debris cover changes in the Greater Caucasus from 1986 to 2014. - The Cryosphere 14: 585-598. https://doi.org/10.5194/tc-14-585-2020

VAlLe, B. (2019): Comunità epiglaciali di piante e artropodi su tre debris-covered glacier dolomitici. - Master Thesis, University of Milan, 108 pp. [in Italian]

VANin, S. \& Turchetto, M. (2007): Winter activity of spiders and pseudoscorpions in the South-Eastern Alps (Italy). - Italian Journal of Zoology 74(1): 31-38. https://doi. org/10.1080/11250000601017233

Woude, H. A. v.d. \& Verhoef, H. A. (1988): Reproductive diapause and cold hardiness in temperate Collembola Orchesella cincta and Tomocerus minor. - Journal of Insect Physiology 34(5): 387-392. https://doi.org/10.1016/0022-1910(88)90108-4

Received August 12, 2020, accepted November 21, 2020, published December 28, 2020 


\section{SUPPLEMENTARY MATERIALS}
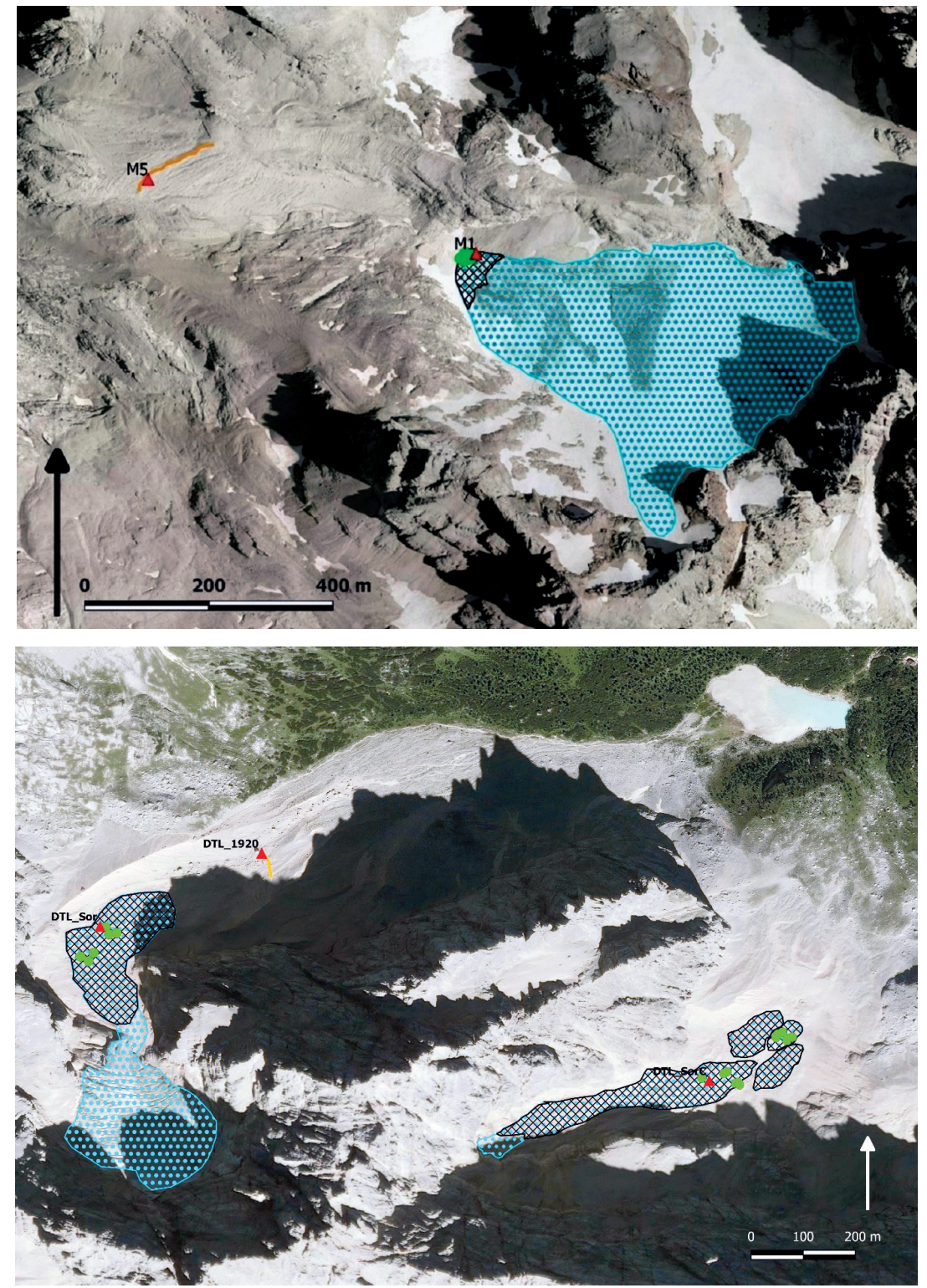

Appendix 1. The sampling plan map of Agola (a) and Sorapiss (b) glaciers. Light-blue pointed polygons: permanent ice; reticulated polygons: supraglacial debris; green points: pitfall traps; red triangles: datalogger positions. M1 = supraglacial datalogger on Agola, M5 = datalogger on 1908 moraines of Agola; DTLSor = supraglacial datalogger on Western Sorapiss; DTLSorC = supraglacial datalogger on Central Sorapiss; DTL 1920 = datalogger on the 1920 moraines of Sorapiss. 


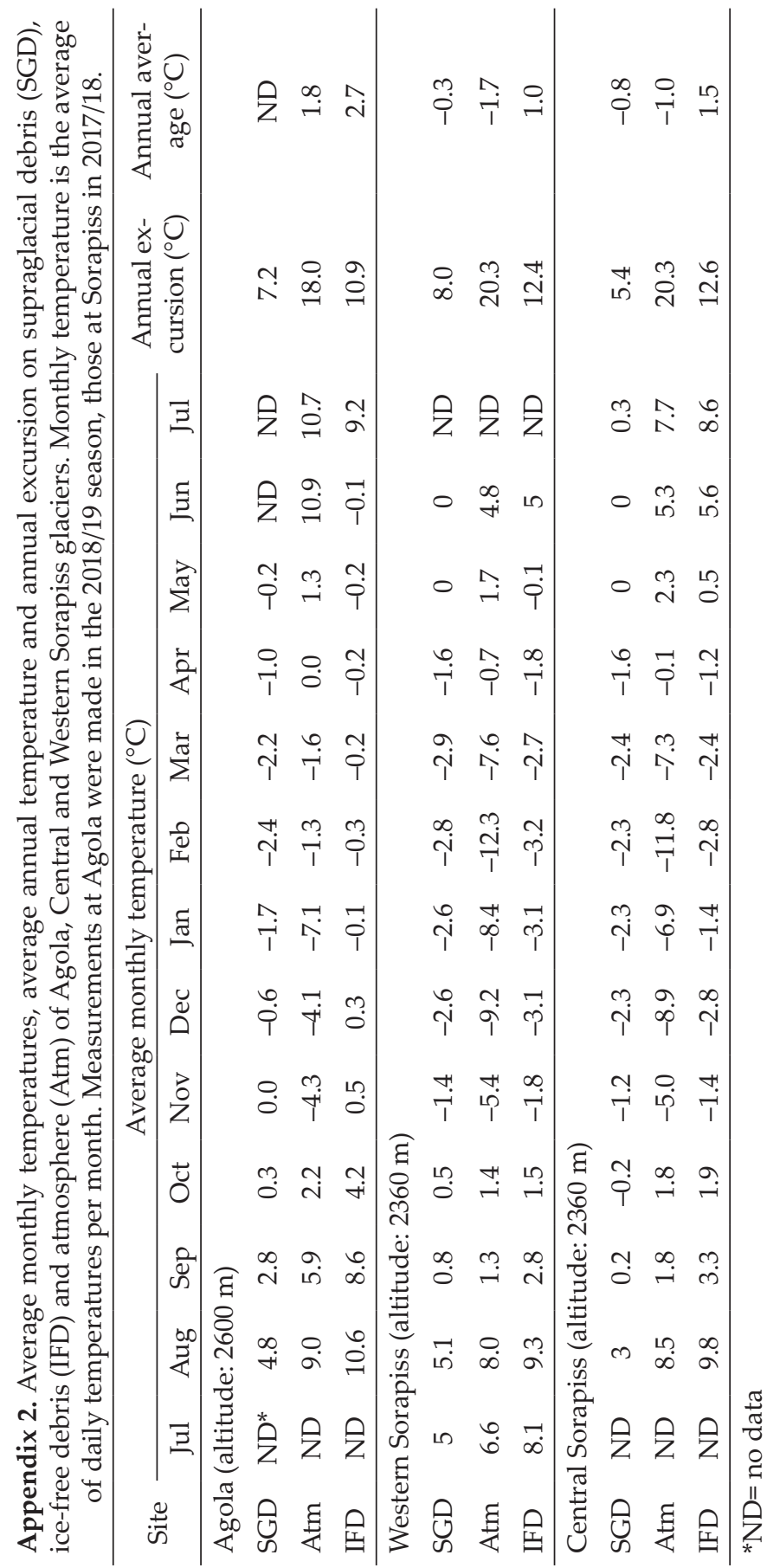



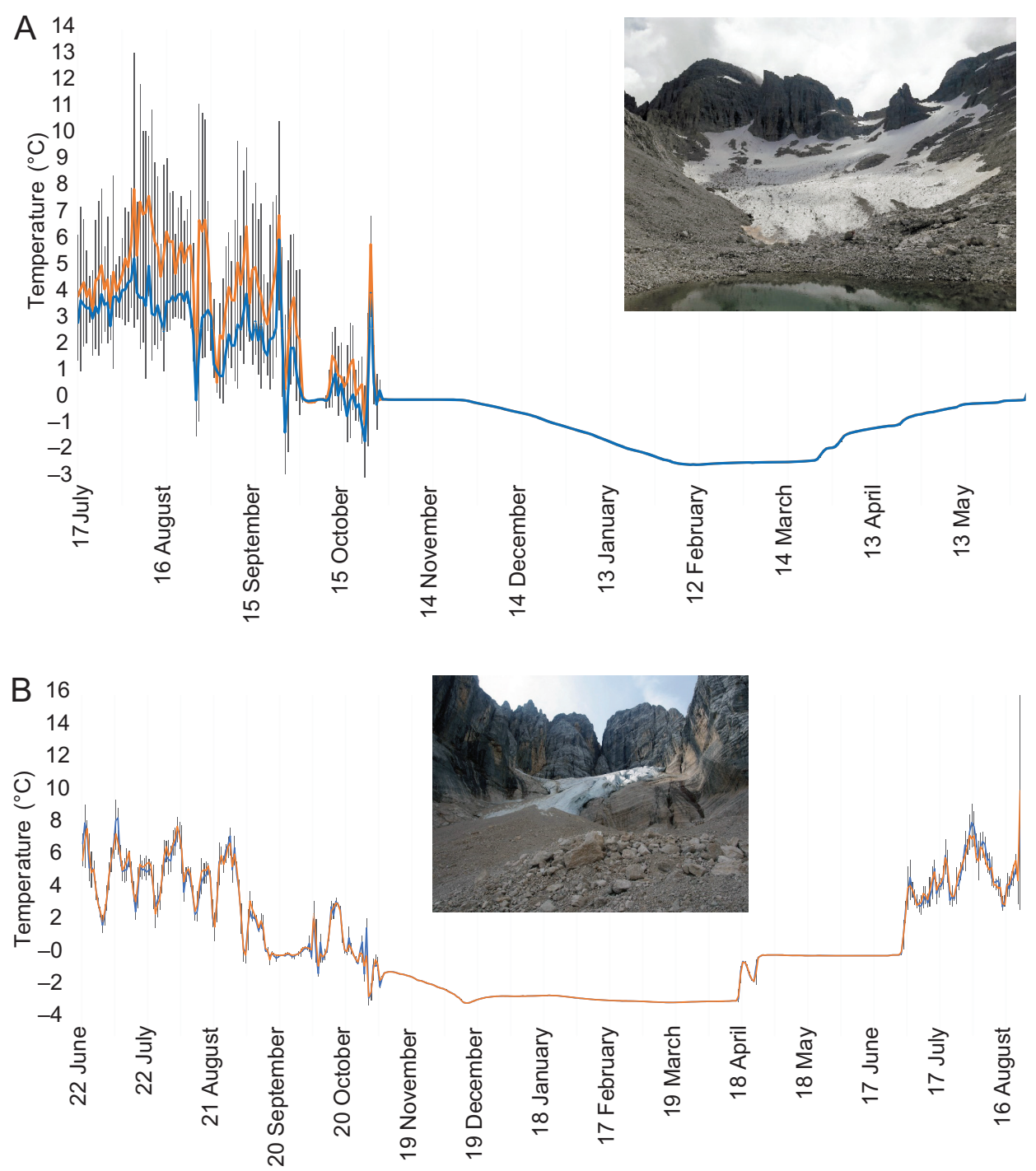

Appendix 3. Temperatures recorded on supraglacial debris at Agola (A) during 2018-2019, Western (B) and Central Sorapiss (C) during 2017-2018. Orange lines indicate average daytime values, blue lines are the average nighttime values. Grey bars indicate \pm S.D. of the daily values. 


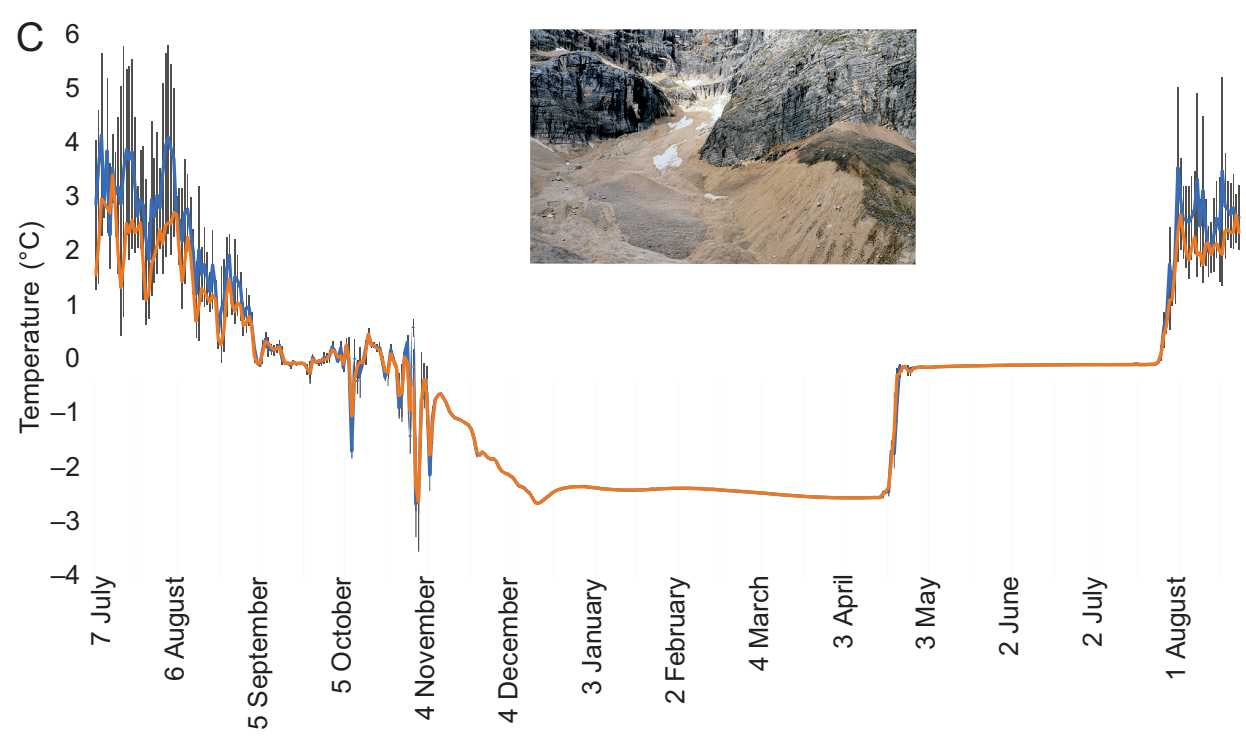

Appendix 3. (continued) Temperatures recorded on supraglacial debris at Agola (A) during 2018-2019, Western (B) and Central Sorapiss (C) during 2017-2018. Orange lines indicate average daytime values, blue lines are the average nighttime values. Grey bars indicate \pm S.D. of the daily values.

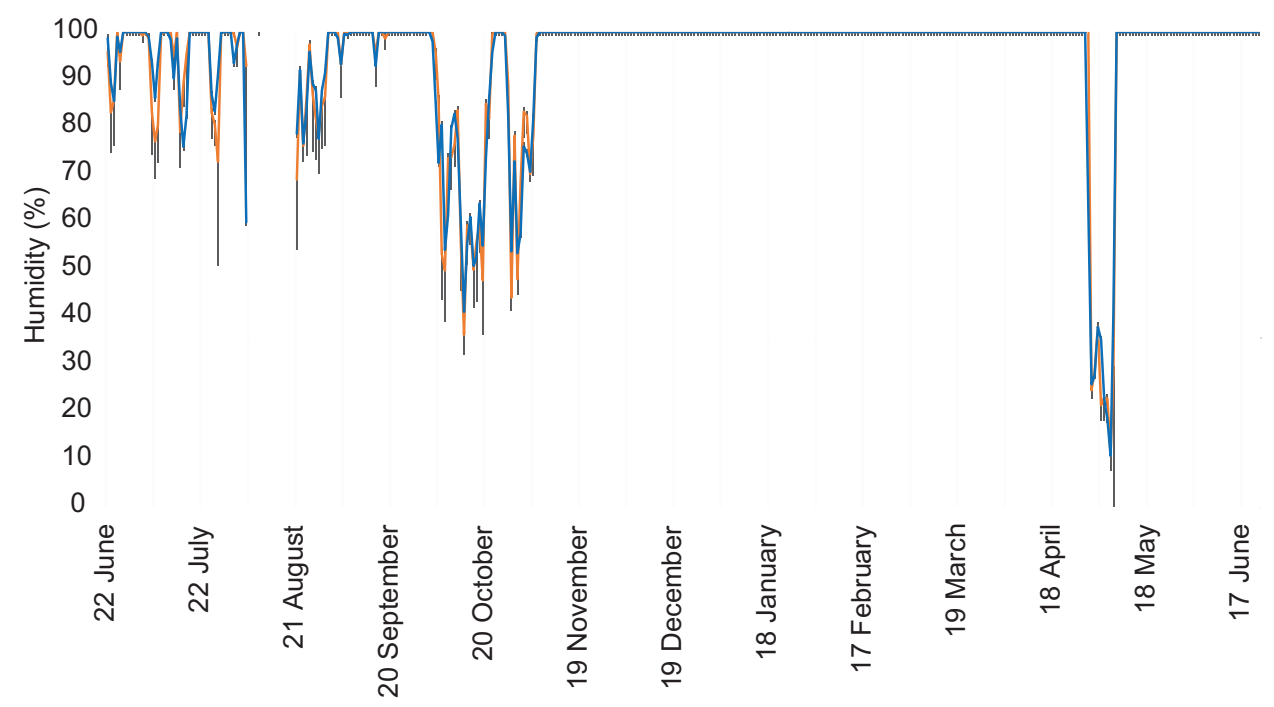

Appendix 4. Relative humidity values recorded on supraglacial debris at the Western Sorapiss glacier during 2017-2018. Orange lines indicate average daytime values, blue lines indicate average nighttime values. 